\title{
PENGEMBANGAN MEDIA PEMBELAJARAN KIMIA BERBANTUAN KOMPUTER DENGAN PROGRAM MACROMEDIA FLASH 8
}

\author{
Edi Bambang Sukamto, Senam \\ SMAN 1 Turi DIY, Universitas Negeri Yogyakarta \\ edi.bambang.sukamto@gmail.com, senamkw@yahoo.com
}

\begin{abstract}
Abstrak
Penelitian ini bertujuan untuk mengembangkan multimedia pembelajaran kimia untuk memecahkan masalah pembelajaran sehingga menjadi media yang menarik dan menyenangkan bagi peserta didik serta menguji kelayakan produk multimedia pembelajaran kimia. Pengembangan multimedia pembelajaran kimia ini dilakukan melalui beberapa tahap, yaitu identifikasi, desain pembelajaran, mengembangkan produk, evaluasi produk, dan implementasi. Subjek uji coba dalam penelitian berjumlah 44 peserta didik, yang terdiri dari 4 orang peserta didik untuk uji coba perorangan, 8 orang peserta didik untuk uji coba kelompok kecil, dan 32 orang peserta didik untuk uji coba kelompok besar. Data hasil uji coba dikumpulkan menggunakan kuesioner. Hasil penelitian menunjukkan bahwa produk multimedia pembelajaran hasil pengembangan, termasuk dalam kategori baik. Demikian juga ahli media menilai kualitas multimedia baik. Berdasarkan hasil tersebut, maka produk multimedia pembelajaran hasil pengembangan layak untuk digunakan.
\end{abstract}

Kata kunci: multimedia pembelajaran kimia, pengembangan

\section{DEVELOPMENT OF COMPUTER ASSISTED LEARNING MEDIA IN CHEMISTRY USING MACROMEDIA FLASH 8}

\author{
Edi Bambang Sukamto, Senam \\ SMAN 1 Turi DIY, Universitas Negeri Yogyakarta \\ edi.bambang.sukamto@gmail.com, senamkw@yahoo.com
}

\begin{abstract}
This research aimed to develop multimedia used in the study of Chemistry in order to solve the issues found in the learning process so that it is seen as a fun and interesting subject for students as well as to examine the product's feasibility in the study of chemistry. Multimedia used in the study of chemistry is being developed through several stages, they are identification, designing the learning process, product development, evaluating the product, and implementation. The test subject in the researchs is 44 participants, divided into 4 participants for the individual tests, 8 participants for the small-group tests, and 32 participants for the larger-group tests. A questionnaire is used in gathering the required data. The results from the research show that the product of the development of multimedia in the learning process falls into the category of good. From the view of the experts in media rates the quality of the media is good. Based on the results, the product of the development of multimedia in the learning process is feasible to be used.
\end{abstract}

Keywords: learning multimedia in chemistry, development 


\section{Pendahuluan}

Bangsa yang besar dengan jumlah penduduk yang banyak dan didukung dengan kualitas Sumber Daya Manusia (SDM) yang baik merupakan modal awal dalam pembangunan suatu bangsa. Kualitas SDM bangsa Indonesia dapat ditingkatkan dengan baik melalui strategi pendidikan dan pembelajaran yang tepat. Dalam menghadapi era globalisasi dirasakan perlu adanya kebutuhan mendesak mengenai perbaikan kualitas SDM melalui pendidikan dan akses yang lebih baik terhadap ilmu pengetahuan. Dengan adanya SDM seperti tersebut diharapkan akan tercapai kehidupan damai, sejahtera, dan diperhitungkan dalam masyarakat dunia.

Pada pendidikan formal, proses pembelajaran pada umumnya bersifat klasikal, termasuk di lingkungan pendidikan persekolahan. Pembelajaran klasikal kurang memperhatikan perbedaan individual. Materi pembelajaran yang dipelajari peserta didik dipersiapkan sama. Setiap peserta didik diharapkan dan dituntut untuk belajar dengan kecepatan yang sama. Kelas yang sesungguhnya bersifat heterogen diperlakukan sebagaimana kelas yang homogen. Perlakuan ini akan mengakibatkan kesulitan sebagian peserta didik dalam mengikuti proses pembelajaran yang selanjutnya dapat mengakibatkan kegagalan belajar peserta didik, sehingga prestasi belajar rendah. Saat ini sebagian besar Sekolah Menengah Atas (SMA) di Indonesia menggunakan pembelajaran klasikal dalam proses pembelajarannya. Pembelajaran klasikal memiliki beberapa kelemahan sebagai berikut: pertama, pembelajaran klasikal mengabaikan perbedaan individual. Kedua, pembelajaran klasikal tidak dapat mengembangkan potensi dalam diri peserta didik secara optimal. Ketiga, guru cenderung berperan dominan dan peserta didik cenderung bersikap pasif dan reseptif.

Pembelajaran individual merupakan suatu strategi untuk mengatur kegiatan pembelajaran sehingga setiap peserta didik memperoleh perhatian lebih banyak daripada yang dapat diberikan dalam kegiatan kelompok pada proses pembelajaran. Latar belakang timbulnya pembelajaran individual diilhami oleh Teori Skinner yang dikenal dengan Reinforcement Theory. Peserta didik memiliki perbedaan karakteristik yang bervariasi dalam belajarnya. Anak sejak dilahirkan memiliki sejumlah potensi namun dalam perkembangannya dan pertumbuhannya, tidak semua potensi dapat berkembang dengan baik. Dikatakan bahwa anak memiliki kepribadian yang unik. Keunikan ini terbentuk oleh perpaduan faktor keturunan (heredity), faktor lingkungan (environment), dan faktor diri (self). Pembelajaran individual (individual instruction) diharapkan sebagai upaya untuk memberikan kesempatan kepada peserta didik agar dapat belajar sesuai kecepatan belajar, kemampuan dengan caranya sendiri dalam belajar. Pembelajaran individual menekankan pada pentingnya perhatian, bantuan, dan perlakuan khusus kepada peserta didik secara individual yang berbeda minat, kemampuan, kebutuhan, serta kecepatan belajarnya.

Banyak peserta didik beranggapan bahwa mata pelajaran kimia merupakan mata pelajaran yang sulit dan tidak menarik, terutama pada materi Hukum-hukum Dasar Kimia dan Stoikiometri. Hal ini kemungkinan disebabkan kesulitan dalam: memahami istilah, bekerja dengan angkaangka, menerapkan rumus-rumus, memahami konsep, dan menggunakan alat-alat laboratorium. Data statistik mengenai rerata nilai Ujian Nasional (UN) di kantor wilayah Dinas Pendidikan dan Kebudayaan DIY dari tahun 2007/2008 sampai 2011/ 2012 rerata mata pelajaran kimia masih rendah. Rerata nilai UN kimia di Daerah Istimewa Yogyakarta tahun pelajaran 2012/ 2013 dan 2013/2014 adalah 7,03 dan 5,59. Dari data rerata nilai UN kimia Daerah Istimewa Yogyakarta di atas dapat disimpulkan bahwa rerata nilai UN mata pelajaran kimia masih rendah. Hal ini menunjukkan bahwa diperlukan adanya peningkatan prestasi belajar kimia dengan mempertimbangkan berbagai faktor yang mempenga- 
ruhi proses pembelajaran dan keberhasilan belajar kimia.

Saat ini, peningkatan proses dan hasil pendidikan kimia harus dapat dilakukan secara efisien dan efektif. Bila hal ini tidak dilakukan, ketertinggalan kita dengan negara lain akan semakin jauh. Berdasarkan hasil diskusi dengan Prof. Dr. Sukardjo, kecenderungan baru (trend) teknologi pembelajaran kimia seharusnya kita cermati dan secara skala prioritas kita laksanakan, sesuai dengan tekad dan kemampuan kita bersama. Perubahan tersebut mengikuti kecenderungan (trend) tertentu, diantaranya: pertama, kurikulum yang semula berorientasi pada materi kimia (subject matter oriented) cenderung berubah menjadi kurikulum yang berorientasi pada hasil (output oriented) dan proses (process oriented) mencapai hasil. Kedua, pembelajaran yang semula berpusat pada guru (teacher centered) cenderung berubah menjadi berpusat pada peserta didik (student centered). Ketiga, pengorganisasian kelas yang semula bersifat klasikal berubah menjadi kelompok, bahkan individual. Keempat, buku ajar yang semula berisi seluruh konsep cenderung berubah menjadi buku ajar yang berisi satu konsep dalam bentuk paket-paket belajar. Kelima, media pembelajaran yang semula berupa media konvensional cenderung berubah menjadi media elektronik.

Pembelajaran kima di SMA perlu mendapat perhatian serius, serta dicarikan terobosan-terobosan baru sehingga pembelajaran kimia meningkat efektivitasnya. Pembelajaran kima lebih ditekankan pada eksplorasi dan investigasi kima. Pembelajaran ini akan membiasakan siswa untuk menggunakan ilmu pengetahuan dalam menyelesaikan berbagai persoalan. Salah satu upaya yang dapat ditempuh adalah dengan melakukan inovasi pada proses pembelajaran, yaitu pembelajaran kimia dengan memanfaatkan multimedia.

Kelebihan multimedia pembelajaran menurut Newby, Stepich, Lehman, dan Russell (2000, pp.166-170) adalah penyajiannya dapat dilakukan dengan model: la- tihan dan praktik, tutorial, simulasi, permainan, dan pemecahan masalah. Dengan demikian pembelajaran kimia menjadi lebih interaktif, menarik dan menyenangkan.

Berkembangnya teknologi informasi dan komunikasi yang begitu cepat, guru bukanlah satu-satunya sumber belajar, tetapi terdapat beraneka ragam sumber belajar lain yang dapat dimanfaatkan, sehingga pembelajaran kimia lebih menarik dan tidak membosankan. Tugas guru yang terutama adalah merencanakan, menciptakan, dan menemukan kegiatan yang bersifat menantang, yang dapat memotivasi siswa untuk berpikir logis, dan yang jauh lebih penting adalah mampu menciptakan pembelajaran yang menyenangkan, sehingga siswa merasa tertarik dan senang untuk belajar. Berawal dari rasa yang senang inilah, dalam diri siswa tumbuh motivasi yang kuat untuk mempelajari suatu materi pelajaran, yang pada gilirannya kompetensi belajar dapat tercapai secara optimal.

Komputer merupakan salah satu media pembelajaran dengan perangkat lunak yang direncanakan, merupakan sarana yang baik dalam membantu proses pembelajaran. Sebagai suatu sistem penyampaian, komputer dipertimbangkan karena mampu melengkapi para peserta didik dengan: model, drill, dan latihan, alat referensi, sistem dan lingkungan simulasi, tes, dan perhitungan yang kompleks (Anderson, 1994, p.195). Pembelajaran berbantuan komputer (PBK) merupakan salah satu alternatif untuk menguatkan efektivitas dan efisiensi pembelajaran kimia. Oleh karena itu sudah selayaknya kalau komputer tidak lagi dipandang sebagai alat bantu bagi guru dalam mengajar, akan tetapi komputer sebagai alat penyalur pesan. Sebagai pembawa pesan PBK dapat digunakan baik oleh guru maupun peserta didik. PBK dapat menjadi penyaji dan penyalur pesan dalam menyampaikan informasi secara lebih teliti, jelas dan menarik tanpa kehadiran guru.

Salah satu ciri yang paling menarik dari pembelajaran berbantuan komputer 
terletak pada kemampuan berinteraksi dengan peserta didik. Dalam pembelajaran berbantuan komputer, peserta didik berhadapan dan berinteraksi langsung dengan komputer. Interaksi antara komputer dengan peserta didik dilakukan secara individual, sehingga apa yang dialami oleh seorang peserta didik akan berbeda dengan apa yang dialami oleh peserta didik lain. Oleh karena potensi inilah teknologi komputer dapat dimanfaatkan dalam sistem pembelajaran. Dengan program seperti ini interaksi dengan sejumlah besar peserta didik dapat berlangsung pada saat yang sama, berbeda dengan interaksi antara guru dan peserta didik yang hanya terjadi secara bergantian sehingga memerlukan waktu lebih lama.

Pemanfaatan komputer sebagai media pembelajaran kimia belum maksimal dilakukan oleh guru. Dari pengalaman peneliti dan guru-guru anggota MGMP (Musyawarah Guru Mata Pelajaran) Kimia menyebutkan bahwa faktor yang menyebabkan hal ini terjadi, antara lain sumber daya guru yang belum terampil menggunakan dan mengembangkan media berbantuan komputer, belum tersedianya sarana yang memadai di sekolah, dan peserta didik yang belum mempersiapkan diri untuk memasuki sistem ini. Guru sebagai ujung tombak pelaksanaan pendidikan di sekolah dituntut untuk senantiasa menyediakan satu suasana yang memungkinkan peserta didik belajar, baik belajar secara mandiri maupun belajar dengan bimbingan guru. Untuk itu maka keberadaan media pembelajaran yang memadai baik secara jenis maupun kualitasnya menjadi sangat penting.

Berdasarkan uraian tersebut, maka kehadiran multimedia pembelajaran yang memenuhi persyaratan yang diperlukan, memungkinkan terjadinya pembelajaran kimia yang lebih efektif dan diharapkan dapat meningkatkan prestasi belajar kimia. Oleh karena itu, peneliti tertarik untuk mengembangkan suatu mutimedia pembelajaran kimia untuk pembelajaran peserta didik di SMA.

\section{Metode Penelitian}

Penelitian ini termasuk penelitian pengembangan pendidikan yang bertujuan untuk menghasilkan produk pembelajaran yang dapat digunakan sesuai kebutuhan. Borg \& Gall (2003, p.772) memberikan batasan tentang penelitian pengembangan sebagai usaha untuk mengembangkan dan memvalidasi produk-produk yang digunakan dalam pendidikan. Sugiyono (2010, p.407) mengemukakan bahwa metode penelitian dan pengembangan adalah metode penelitian yang digunakan untuk untuk menghasilkan produk tertentu, dan menguji keefektifan produk tersebut. Sayodih (2006, p.164) memberikan pengertian tentang penelitian dan pengembangan sebagai suatu proses atau langkah-langkah untuk mengembangkan suatu produk baru atau menyempurnakan produk yang telah ada, yang dapat dipertanggungjawabkan. Produk tersebut tidak selalu berbentuk benda atau perangkat keras (hardware), tetapi bisa juga perangkat lunak (software). Berdasarkan berbagai pendapat tersebut dapat ditarik kesimpulan bahwa penelitian pengembangan di bidang pendidikan merupakan suatu jenis penelitian untuk menghasilkan produk-produk untuk kepentingan pendidikan/pembelajaran melalui pengembangan dan validasi produk-produknya, kemudian produk diakhiri dengan evaluasi.

Model pengembangan yang digunakan dalam penelitian ini menggunakan perpaduan model pengembangan dari Borg \& Gall (2003, p.775), Dick \& Carey (2005, pp.6-8) dan Criswell (1989, p.50) yang telah dipadukan. Hal ini dilakukan agar lebih sederhana dan mudah dipahami. Model pengembangan hasil perpaduan tersebut memiliki lima tahap sebagai berikut: (1) analisis, pada tahap ini kegiatan yang dilakukan adalah menganalisis kebutuhan dan karakteristik siswa, menganalisis kurikulum untuk menetapkan kompetensi hasil belajar, memilih dan menetapkan materi pokok yang akan dikembangkan, dan mengembangkan alat evaluasi, (2) 
desain, pada tahap ini, pengembang membuat storyboard dan flowchart, (3) produksi, pada tahap ini dilakukan pengemasan materi ke dalam CD sesuai storyboard yang telah dibuat, (4) uji coba dan revisi, sebelum uji coba dilaksanakan, dilakukan review oleh ahli materi dan ahli media terhadap produk multimedia yang dikembangkan, (5) implementasi, pada tahap ini produk mulimedia pembelajaran hasil pengembangan disebarluaskan ke semua pengguna.

\section{Subjek Uji Coba}

Subjek coba produk ini adalah peserta didik kelas X SMA Negeri 1 Turi, Sleman dengan rincian sebagai berikut. Jumlah peserta didik kelas $X$ ada 96 orang peserta didik diambil sampel 4 peserta didik untuk uji coba satu-satu dan 8 peserta didik untuk uji coba kelompok kecil dipilih secara acak dan 32 peserta didik untuk uji coba kelompok besar. Uji coba untuk validasi produk melibatkan satu orang ahli media dan satu orang ahli materi.

Prosedur

Agar tujuan pengembangan ini dapat berhasil dengan baik maka perlu didukung berbagai data. Jenis data yang digali adalah sebagai berikut: (1) aspek pembelajaran dan kebenaran isi diperoleh dari ahli materi dan rancangan pembelajaran, (2) media dan rancangan pembelajaran diperoleh dari ahli media, (3) kualitas tampilan dan penyajian materi, diperoleh dari uji coba perorangan dan lapangan, (4) daya tarik pembelajaran berbantuan komputer diperoleh dari aktivitas dan respon peserta didik selama uji coba pembelajaran berbantuan komputer mata pelajaran kimia.

Data yang diperoleh disesuaikan dengan tujuan dan desain pengembangan yang digunakan maka jenis data yang dikumpulkan dalam pengembangan ini adalah data kuantitatif sebagai data pokok, yang terkumpul melalui angket dengan skala penilaian 1 sampai 5 (1: sangat kurang bagus, 2: kurang bagus, 3: cukup, 4: bagus dan 5: sangat bagus). Para responden akan memberi angka penilaian pada setiap butir angket berdasarkan kriteria yang telah ditetapkan. Selain itu jenis data yang dikumpulkan adalah data kualitatif berupa saran dan masukan tertulis oleh responden sebagai data tambahan.

Instrumen pengumpulan data pada pengembangan ini adalah alat-alat yang dipakai untuk memperoleh data dan informasi dalam rangka menilai atau memperbaiki produk. Instrumen dalam penelitian digunakan untuk mengetahui kualitas multimedia pembelajaran kimia bagi peserta didik SMA kelas $X$ dari aspek pembelajaran, materi, dan media sehingga pengukurannya digunakan instrumen yang berupa lembar angket. Lembar angket digunakan untuk mengukur kualitas multimedia pembelajaran yang dikembangkan, dari aspek pembelajaran, materi, dan media. Lembar angket yang dipakai sebagai instrumen untuk mengumpulkan data meliputi dua jenis, sesuai dengan peran dan posisi responden, yaitu: (1) lembar angket untuk ahli materi dan ahli media pembelajaran dalam rangka tinjauan ahli terhadap produk hasil pengembangan, (2) lembar angket untuk peserta didik sebagai pemakai produk dalam rangka evaluasi formatif terhadap produk hasil pengembangan.

\section{Teknik Analisis Data}

Teknik analisis data dalam penelitian ini dilakukan dengan langkah-langkah sebagai berikut: Pertama, hasil review dari ahli materi dan peserta didik dalam bentuk nilai angka seperti Tabel 1 .

Tabel 1. Nilai Angka Hasil Review dari Ahli Materi dan Peserta Didik

\begin{tabular}{lc}
\hline Hasil Penilaian & Nilai Angka \\
\hline Sangat jelas & 5 \\
Jelas & 4 \\
Cukup jelas & 3 \\
Tidak jelas & 2 \\
Sangat tidak jelas & 1 \\
\hline
\end{tabular}


Kedua, hasil review dari ahli media dalam bentuk nilai angka seperti Tabel 2 .

Tabel 2. Nilai Angka Hasil Review dari Ahli Media

\begin{tabular}{cc}
\hline Hasil Penilaian & Nilai Angka \\
\hline Sangat bagus & 5 \\
Bagus & 4 \\
Cukup & 3 \\
Kurang & 2 \\
Sangat kurang & 1 \\
\hline
\end{tabular}

Dari aspek yang direview, kemudian dicari rata-rata empirisnya dengan rumus:

$$
\bar{x}=\frac{\sum X}{n}
$$

$\bar{x}=$ Skor rata-rata

$\sum X=$ Jumlah skor

$n \quad=$ Jumlah responden

Untuk mengetahui kualitas PBK, data masing-masing variabel dikategorikan menjadi 5 kelas. Kelima kategori tersebut adalah (1) sangat tinggi, (2) tinggi, (3) sedang, (4) rendah, dan (5) sangat rendah. Dasar penentuan kelima kategori tersebut menurut Sukardjo (2005, pp.52-53), adalah jika X empiris seperti pada Tabel 3.

Tabel 3. Kategori Penilaian

\begin{tabular}{cc}
\hline Nilai & Kriteria \\
\hline$X>\mathrm{Mi}+1,80 \mathrm{SBi}$ & Sangat Tinggi \\
$\mathrm{Mi}+0,60 \mathrm{SBi}<\mathrm{X} \leq \mathrm{Mi}+1,80 \mathrm{SBi}$ & Tinggi \\
$\mathrm{Mi}-0,60 \mathrm{SBi}<\mathrm{X} \leq \mathrm{Mi}+0,60 \mathrm{SBi}$ & Sedang \\
$\mathrm{Mi}-1,80 \mathrm{SBi}<\mathrm{X} \leq \mathrm{Mi}-0,60 \mathrm{SBi}$ & Rendah \\
$\mathrm{X} \leq \mathrm{Mi}-1,80 \mathrm{SBi}$ & Sangat Rendah \\
\hline
\end{tabular}

Keterangan:

Mi adalah mean ideal, dihitung dengan menggunakan rumus sebagai berikut.

$\mathrm{Mi}=1 / 2$ (skor terendah - skor tertinggi).

SBi adalah simpangan baku ideal, ditentukan dengan rumus sebagai berikut. $\mathrm{SBi}=1 / 6$ (skor tertinggi - skor terendah)

\section{Hasil Penelitian dan Pembahasan}

Dalam uji coba produk diperoleh lima jenis data, yaitu data validasi dari ahli materi dan ahli media, data uji coba perorangan, data uji coba kelompok kecil, dan data uji coba kelompok besar. Ahli materi mengevaluasi multimedia pembelajaran hasil pengembangan dari aspek pembelajaran dan aspek materi. Sedangkan ahli media mengevaluasi multimedia pembelajaran hasil pengembangan dari aspek media. Hasil evaluasi dari ahli materi dan ahli media digunakan untuk merevisi multimedia pembelajaran dan mengukur layak atau tidak layak multimedia yang dikembangkan tersebut untuk diujicobakan di lapangan.

Data yang diperoleh dari hasil uji coba perorangan dan uji coba kelompok kecil digunakan untuk perbaikan produk sebelum dilakukan uji coba kelompok besar. Data yang diperoleh dari hasil uji coba kelompok besar digunakan untuk mengukur kualitas multimedia yang dikembangkan dari aspek pembelajaran, aspek materi, dan aspek media.

Data tentang Tanggapan Ahli Materi terhadap Multimedia Pembelajaran Hasil Pengembangan

Ahli materi dalam produk penelitian ini adalah Dra. Magdalena Sri Pratiwi, M.M. Beliau adalah guru mata pelajaran kimia di SMA Bopkri 1. Penilaian yang dilakukan oleh ahli materi terhadap multimedia pembelajaran hasil pengembangan terdiri dari dua aspek, yaitu aspek pembelajaran dan aspek materi. Penilaian oleh ahli materi tersebut dilakukan dengan menggunakan kuesioner. Kuesioner ahli materi untuk aspek pembelajaran terdiri atas 18 aspek dan kuesioner untuk aspek materi terdiri atas 10 aspek. Untuk memperoleh produk multimedia yang layak, ahli materi juga memberikan komentar dan saransaran yang berkaitan dengan aspek pembelajaran maupun aspek materi. Ahli materi memberikan penilaian dari aspek pembelajaran dan aspek materi termasuk 
kategori baik. Skor rata-rata untuk aspek pembelajaran 4,00 dengan kategori baik dan skor rata-rata untuk aspek materi 4,00 dengan kategori baik. Skor rata-rata keseluruhan 4,00 termasuk dalam kategori baik.

Data tentang Tanggapan Ahli Media terhadap Multimedia Pembelajaran Hasil Pengembangan

Ahli media dalam produk penelitian ini adalah Herman Dwi Surjono, M.Sc., M.T., Ph.D.. Beliau adalah dosen Multimedia, Kepala Program Studi Teknologi Pembelajaran Program Pascasarjana Universitas Negeri Yogyakarta.

Data yang diperoleh dari hasil penilaian ahli media terhadap multimedia pembelajaran hasil pengembangan, hanya satu aspek yaitu aspek media. Penilaian oleh ahli media tersebut dilakukan dengan menggunakan kuesioner. Kuesioner terdiri atas 20 pertanyaan. Untuk memperoleh produk multimedia yang layak, ahli media memberikan komentar dan saran terhadap produk yang dikembangkan. Ahli media memberikan penilaian dari aspek media dengan kategori baik. Rata-rata keseluruhan 4,00 termasuk dalam kategori baik.

Data tentang Tanggapan Peserta Didik dalam Uji Coba Perorangan

Setelah produk multimedia dilakukan uji kelayakan oleh ahli materi dan ahli media, kemudian dilakukan uji coba perorangan kepada peserta didik SMA Negeri 1 Turi. Uji coba ini diikuti peserta didik sebanyak 4 orang. Pemilihan keempat peserta didik tersebut dilakukan oleh guru yang mengajar kimia kelas $X$ di SMA tersebut. Data yang diperoleh dari uji coba ini digunakan sebagai dasar untuk melakukan revisi produk sebelum digunakan pada uji coba kelompok kecil.

Data tentang tanggapan peserta didik pada uji coba perorangan ini diperoleh melalui kuesioner yang diberikan. Uji coba dilaksanakan di laboratorium komputer SMA Negeri 1 Turi pada tanggal 20 Agustus 2013. Peserta didik pada uji coba per- orangan memberikan penilaian dari aspek pembelajaran, aspek materi, dan aspek media. Skor rata-rata untuk aspek pembelajaran 4,10 dengan kategori baik, skor rata-rata untuk aspek materi 4,22 dengan kategori sangat baik, dan skor rata-rata aspek media 4,13 dengan kategori baik. Skor rata-rata keseluruhan 4,15 termasuk dalam kategori baik. Perbandingan skor rata-rata yang diperoleh pada uji coba perorangan diperlihatkan pada Gambar 1.

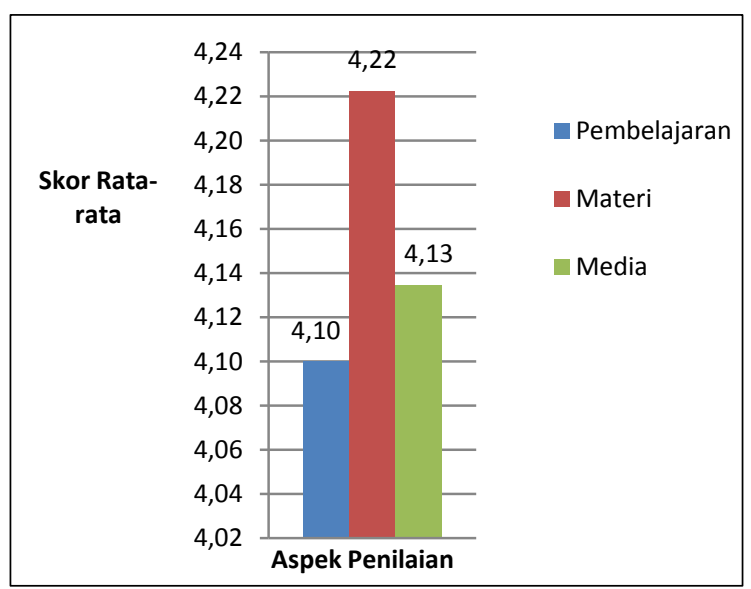

Gambar 1. Perbandingan Skor Rata-rata yang Diperoleh pada Uji Coba Perorangan

Data tentang Tanggapan Peserta Didik dalam uji Coba Kelompok Kecil

Uji coba kelompok kecil diberikan kepada 8 peserta didik kelas X SMA Negeri 1 Turi yang dilakukan di laboratorium komputer SMA Negeri 1 Turi pada tanggal 21 Agustus 2013. Penentuan responden pada uji coba ini dilakukan oleh guru yang mengajar kelas X di SMA tersebut. Pada uji coba kelompok kecil ini peserta didik memberikan penilaian dari aspek pembelajaran, aspek materi dan aspek media. Skor rata-rata untuk aspek pembelajaran 4,16 dengan kategori baik, skor rata-rata untuk aspek materi 4,13 dengan kategori baik dan skor rata-rata untuk aspek media 4,25 dengan kategori sangat baik. Rata-rata skor keseluruhan 4,18 termasuk dalam kategori baik. Perbandingan skor rata-rata yang diperoleh pada uji coba kelompok kecil diperlihatkan pada Gambar 2. 


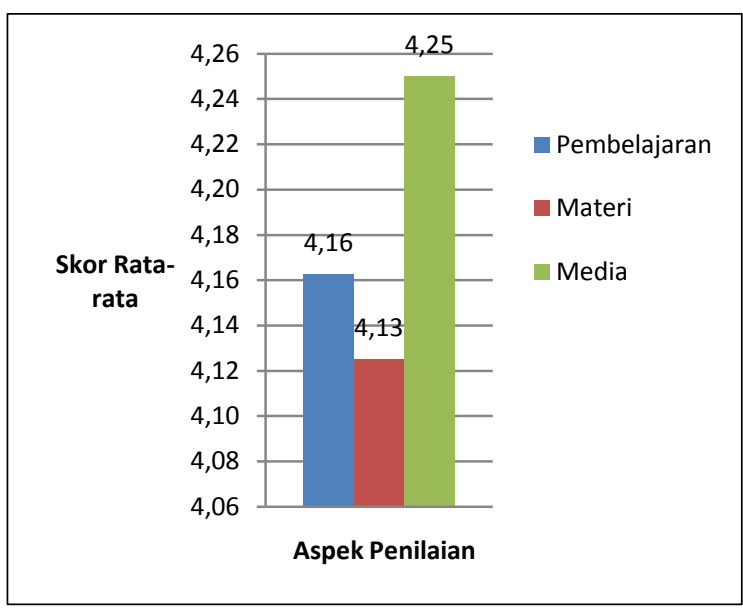

Gambar 2. Perbandingan Skor Rata-rata yang Diperoleh pada Uji Coba Kelompok Kecil

Data tentang Tanggapan Peserta Didik dalam Uji Coba Kelompok Besar

Uji coba kelompok besar diberikan kepada 32 peserta didik kelas X SMA Negeri 1 Turi yang dilakukan di laboratorium komputer SMA Negeri 1 Turi pada tanggal 22 Agustus 2013. Penentuan responden pada uji coba ini dilakukan oleh guru yang mengajar kelas $X$ di SMA Negeri 1 Turi. Data terdiri dari tiga aspek, yaitu aspek pembelajaran, aspek materi dan aspek media yang diperoleh melalui kuesioner dan hasilnya diuraikan sebagai berikut:

\section{Aspek Pembelajaran}

Data tanggapan peserta didik pada uji coba kelompok besar dari aspek pembelajaran diperoleh skor pada setiap butir pernyataan termasuk dalam kategori baik dan sangat baik. Rata-rata skor keseluruhan 4,07 dengan kategori baik.

Distribusi tanggapan peserta didik terhadap multimedia pembelajaran hasil pengembangan pada aspek pembelajaran yaitu: 66 tanggapan cukup, 167 tanggapan baik, dan 87 tanggapan sangat baik. Distribusi tanggapan peserta didik dalam uji coba kelompok besar dari aspek pembelajaran, disajikan juga dengan diagram batang seperti terlihat dalam Gambar 3.

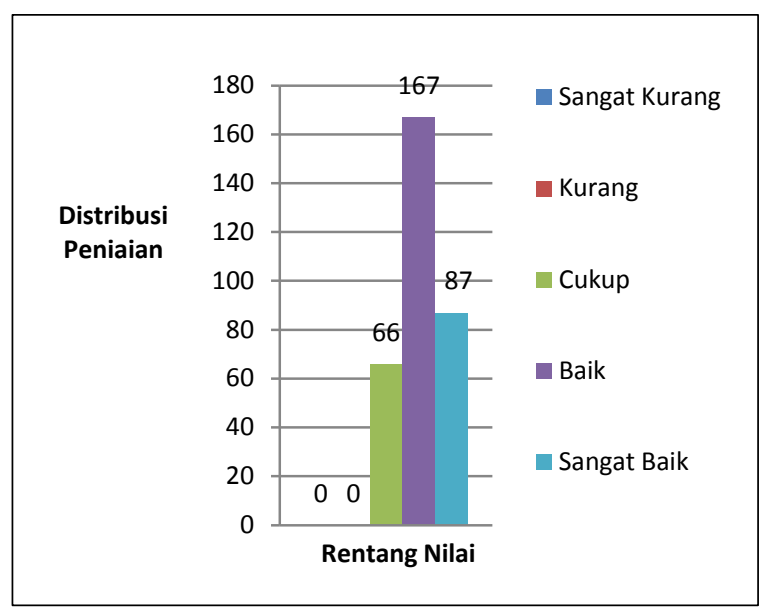

Gambar 3. Distribusi Tanggapan Peserta Didik dalam Uji Coba Kelompok Besar terhadap Multimedia Pembelajaran Kimia Hasil Pengembangan dari Aspek Pembelajaran

Aspek Materi

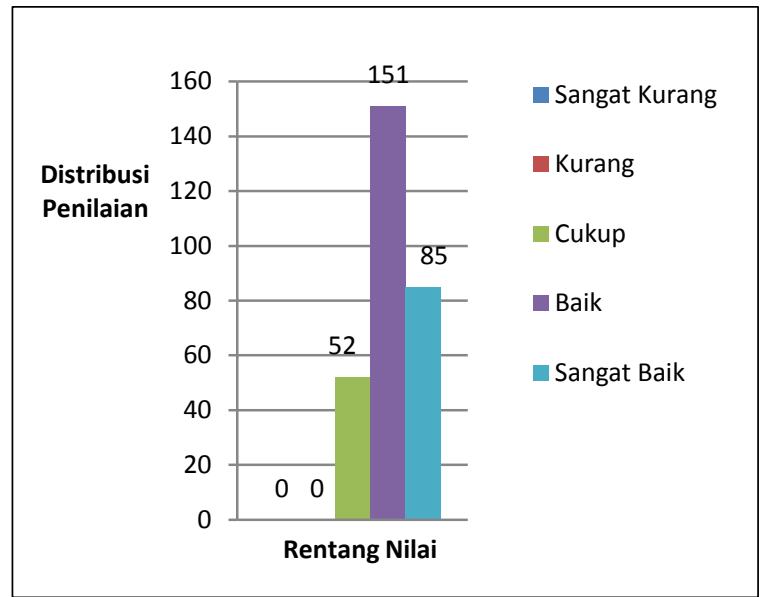

Gambar 4. Distribusi Tanggapan Peserta Didik dalam Uji Coba Kelompok Besar terhadap Multimedia Pembelajaran Kimia Hasil Pengembangan dari Aspek Materi

Data tanggapan peserta didik pada uji coba kelompok besar dari aspek materi diperoleh rata-rata skor keseluruhan 4,11 dengan kategori baik. Distribusi tanggapan peserta didik terhadap multimedia pembelajaran hasil pengembangan pada aspek materi yaitu: 52 tanggapan cukup, 151 tanggapan baik, dan 85 tanggapan sangat baik. Distribusi tanggapan peserta didik 
dalam uji coba kelompok besar dari aspek materi, disajikan juga dengan diagram batang seperti terlihat dalam Gambar 4 .

\section{Aspek Media}

Data tanggapan peserta didik pada uji coba kelompok besar dari aspek media diperoleh skor pada setiap butir pernyataan termasuk dalam kategori baik dan sangat baik. Rata-rata skor keseluruhan 4,23 dengan kategori sangat baik. Distribusi tanggapan peserta didik terhadap multimedia pembelajaran hasil pengembangan pada aspek media yaitu: 58 tanggapan cukup, 203 tanggapan baik, dan 155 tanggapan sangat baik. Distribusi tanggapan peserta didik dalam uji coba kelompok besar dari aspek media, disajikan juga dengan diagram batang seperti terlihat dalam Gambar 5.

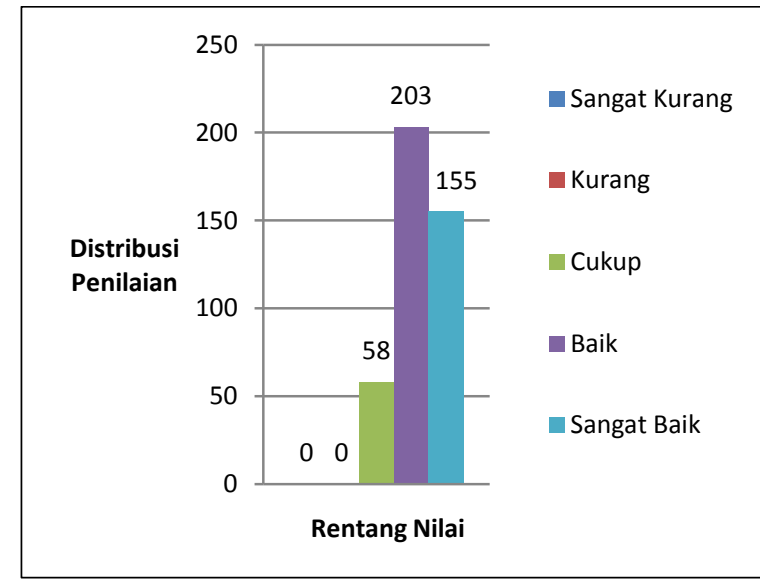

Gambar 5. Distribusi Tanggapan Peserta Didik dalam Uji Coba

Kelompok Besar terhadap

Multimedia Pembelajaran

Kimia Hasil Pengembangan dari Aspek Media

\section{Analisis Data Hasil Penilaian Ahli Materi}

Ahli materi memberikan penilaian pada aspek pembelajaran dengan nilai rata-rata 4,00 termasuk kriteria baik dan pada aspek materi dengan nilai rata-rata 4,00 termasuk kriteria baik. Rata-rata skor keseluruhan dari aspek pembelajaran dan aspek materi yaitu: 4,00 setelah dikonversikan ke skala 5 termasuk kriteria baik. Di- lakukan revisi sesuai saran dari ahli materi untuk penyempurnaan produk. Berdasarkan hasil penilaian dari ahli materi, produk multimedia pembelajaran ini dinyatakan layak untuk diujicobakan di lapangan.

\section{Analisis Data Hasil Penilaian Ahli Media}

Hasil analisis data penilaian dari ahli media diperoleh skor rata-ratanya 4,00 setelah dikonversikan ke skala 5 termasuk kategori baik. Revisi dilakukan sesuai saran ahli media. Berdasarkan hasil penilaian dari ahli media, produk multimedia pembelajaran kimia ini dinyatakan layak untuk diujicobakan di lapangan.

\section{Analisis Data Hasil Uji Coba Perorangan}

Ada tiga aspek yang dianalisis pada uji coba perorangan yaitu: aspek pembelajaran, aspek materi, dan aspek media. Diperoleh skor rata-rata untuk aspek pembelajaran yaitu 4,10 setelah dikonversikan pada skala 5 berarti termasuk kategori baik. Skor rata-rata untuk aspek materi yaitu 4,22 setelah dikonversikan pada skala 5 berarti termasuk kategori sangat baik, dan skor rata-rata aspek media yaitu 4,13 setelah dikonversikan pada skala 5 berarti termasuk kategori baik. Skor rata-rata keseluruhan adalah 4,15 setelah dikonversikan pada skala 5 berarti termasuk kategori baik.

Berdasarkan hasil analisis uji coba perorangan, dapat dikatakan bahwa produk multimedia pembelajaran kimia hasil pengembangan ditinjau dari aspek pembelajaran, aspek materi maupun aspek media mendapat nilai B termasuk dalam kategori baik, sehingga layak untuk digunakan pada uji coba kelompok kecil.

\section{Analisis Data Hasil Uji Coba Kelompok Kecil}

Ada tiga aspek yang dianalisis pada uji coba kelompok kecil, yaitu: aspek pembelajaran, aspek materi, dan aspek media. Diperoleh skor rata-rata untuk aspek pembelajaran yaitu 4,16 setelah dikonversikan pada skala 5 berarti termasuk 
kategori baik. Skor rata-rata untuk aspek materi yaitu 4,13 setelah dikonversikan pada skala 5 berarti termasuk kategori baik, dan skor rata-rata aspek media yaitu 4,25 setelah dikonversikan pada skala 5 berarti termasuk kategori sangat baik. Skor rata-rata keseluruhan yaitu 4,18 setelah dikonversikan pada skala 5 berarti termasuk kategori baik.

Berdasarkan hasil analisis uji coba kelompok kecil, dapat dikatakan bahwa produk multimedia pembelajaran kimia hasil pengembangan ditinjau dari aspek pembelajaran, aspek materi maupun aspek media mendapat nilai B termasuk dalam kategori baik, sehingga layak untuk digunakan pada uji coba kelompok besar.

\section{Analisis Data Hasil Uji Coba Kelompok Besar}

\section{Aspek Pembelajaran}

Responden sebanyak 32 peserta didik memberikan penilaian terhadap produk multimedia pembelajaran kimia hasil pengembangan dari aspek pembelajaran, diperoleh rata-rata skor keseluruhan yaitu 4,07 setelah dikonversikan pada skala 5 termasuk kategori baik.

Distribusi penilaian peserta didik terhadap multimedia pembelajaran hasil pengembangan pada aspek pembelajaran secara keseluruhan yaitu: 66 tanggapan cukup, 167 tanggapan baik, dan 87 tanggapan sangat baik. Sedangkan penjelasan tiap butir, dipaparkan secara detail sebagai berikut: (1) pada butir kejelasan petunjuk belajar, responden memberikan penilaian cukup sebanyak 1 , baik sebanyak 20 , dan sangat baik sebanyak 11 . Skor rata-rata keseluruhan penilaian pada kejelasan petunjuk belajar sebesar 4,31 setelah dikonversikan pada skala 5 termasuk kategori sangat baik, (2) pada butir kejelasan rumusan kompetensi belajar, responden memberikan penilaian cukup sebanyak 3 , baik sebanyak 26, dan sangat baik sebanyak 3 . Skor rata-rata keseluruhan penilaian pada butir kejelasan rumusan kompetensi belajar sebesar 4 setelah dikonversikan pada skala
5 termasuk kategori baik, (3) pada butir kemudahan untuk mempelajari, responden memberikan penilaian cukup sebanyak 7, baik sebanyak 18, dan sangat baik sebanyak 7. Skor rata-rata keseluruhan penilaian pada butir kemudahan untuk mempelajari sebesar 4 setelah dikonversikan pada skala 5 termasuk kategori baik, (4) pada butir kejelasan keruntutan materi, responden memberikan penilaian cukup sebanyak 9, baik sebanyak 13, dan sangat baik sebanyak 10. Skor rata-rata keseluruhan penilaian pada butir kejelasan keruntutan materi sebesar 4,03 setelah dikonversikan pada skala 5 termasuk kategori baik, (5) pada butir kejelasan contoh-contoh yang diberikan, responden memberikan penilaian cukup sebanyak 6, baik sebanyak 13, dan sangat baik sebanyak 13 . Skor rata-rata keseluruhan penilaian pada butir kejelasan contoh-contoh yang diberikan sebesar 4,22 setelah dikonversikan pada skala 5 termasuk kategori sangat baik, (6) pada butir kejelasan petunjuk mengerjakan soal, responden memberikan penilaian cukup sebanyak 10, baik sebanyak 14, dan sangat baik sebanyak 8 . Skor rata-rata keseluruhan penilaian pada butir kejelasan petunjuk mengerjakan soal sebesar 3,94 setelah dikonversikan pada skala 5 termasuk kategori baik, (7) pada butir latihan soal untuk pemahaman materi, responden memberikan penilaian cukup sebanyak 6, baik sebanyak 16, dan sangat baik sebanyak 10 . Skor rata-rata keseluruhan penilaian pada butir latihan soal untuk pemahaman materi sebesar 4,13 setelah dikonversikan pada skala 5 termasuk kategori baik, (8) pada butir ketertarikan penyampaian materi, responden memberikan penilaian cukup sebanyak 7 , baik sebanyak 13 , dan sangat baik sebanyak 12 . Skor rata-rata keseluruhan penilaian pada butir ketertarikan penyampaian materi sebesar 4,16 setelah dikonversikan pada skala 5 termasuk kategori baik, (9) pada butir respon terhadap jawaban benar, responden memberikan penilaian cukup sebanyak 10, baik sebanyak 12 , dan sangat baik sebanyak 10 . Skor ratarata keseluruhan penilaian pada butir 
respon terhadap jawaban benar sebesar 4 setelah dikonversikan pada skala 5 termasuk kategori baik, (10) pada butir respon terhadap jawaban salah, responden memberikan penilaian cukup sebanyak 7 , baik sebanyak 22, dan sangat baik sebanyak 3 . Skor rata-rata keseluruhan penilaian pada butir respon terhadap jawaban salah sebesar 3,88 setelah dikonversikan pada skala 5 termasuk kategori baik.

\section{Aspek Materi}

Responden sebanyak 32 peserta didik memberikan penilaian terhadap produk multimedia pembelajaran kimia hasil pengembangan dari aspek materi, diperoleh rata-rata skor keseluruhan 4,11 setelah dikonversikan pada skala 5 termasuk kategori baik.

Distribusi penilaian peserta didik terhadap multimedia pembelajaran hasil pengembangan pada aspek materi secara keseluruhan yaitu: 52 tanggapan cukup, 151 tanggapan baik, dan 85 tanggapan sangat baik. Sedangkan penjelasan tiap butir, dipaparkan secara detail sebagai berikut: (1) pada butir kejelasan materi, responden memberikan penilaian sangat baik sebanyak 6 , dan baik sebanyak 26 . Skor ratarata keseluruhan penilaian pada butir kejelasan materi sebesar 4,19 setelah dikonversikan pada skala 5 termasuk kategori baik, (2) pada butir kemenarikan materi yang dipelajari, responden memberikan penilaian sangat baik sebanyak 14, baik sebanyak 15 , dan cukup sebanyak 3 . Skor rata-rata keseluruhan penilaian pada butir kemenarikan materi yang dipelajari sebesar 4,34 setelah dikonversikan pada skala 5 termasuk kategori sangat baik, (3) pada butir kejelasan bahasa, responden memberikan penilaian sangat baik sebanyak 12 , baik sebanyak 11, dan cukup sebanyak 9 . Skor rata-rata keseluruhan penilaian pada butir kejelasan bahasa sebesar 4,09 setelah dikonversikan pada skala 5 termasuk kategori baik, (4) pada butir kemudahan materi yang dipelajari, responden memberikan penilaian sangat baik sebanyak 6, baik sebanyak 18, dan cukup sebanyak 8 . Skor rata-rata keseluruhan penilaian pada butir kemudahan materi yang dipelajari sebesar 3,94 setelah dikonversikan pada skala 5 termasuk kategori baik, (5) pada butir kejelasan kalimat pada uraian materi, responden memberikan penilaian sangat baik sebanyak 5, baik sebanyak 19, dan cukup sebanyak 8. Skor rata-rata keseluruhan penilaian pada butir kejelasan kalimat pada uraian materi sebesar 3,91 setelah dikonversikan pada skala 5 termasuk kategori baik, (6) pada butir kejelasan petunjuk pengerjaan soal, responden memberikan penilaian sangat baik sebanyak 7 , baik sebanyak 19 , cukup sebanyak 6 . Skor ratarata keseluruhan penilaian pada butir kejelasan petunjuk pengerjaan soal sebesar 4,03 setelah dikonversikan pada skala 5 termasuk kategori baik, (7) pada butir tingkat kesulitan soal, responden memberikan penilaian sangat baik sebanyak 7 , baik sebanyak 18, dan cukup sebanyak 7 . Skor rata-rata keseluruhan penilaian pada butir tingkat kesulitan soal materi sebesar 4 setelah dikonversikan pada skala 5 termasuk kategori baik, (8) pada butir kejelasan tulisan, responden memberikan penilaian sangat baik sebanyak 14 , baik sebanyak 16 , dan cukup sebanyak 2 . Skor rata-rata keseluruhan penilaian pada butir kejelasan tulisan sebesar 4,38 setelah dikonversikan pada skala 5 termasuk kategori sangat baik, (9) pada butir kemanfaatan gambar, responden memberikan penilaian sangat baik sebanyak 14, baik sebanyak 9, dan cukup sebanyak 9. Skor rata-rata keseluruhan penilaian pada butir kemanfaatan gambar sebesar 4,16 setelah dikonversikan pada skala 5 termasuk kategori baik.

\section{Aspek Media}

Responden sebanyak 32 peserta didik memberikan penilaian terhadap produk multimedia pembelajaran kimia hasil pengembangan dari aspek media, diperoleh rata-rata skor keseluruhan 4,23 setelah dikonversikan pada skala 5 termasuk kategori sangat baik. 
Distribusi penilaian peserta didik terhadap multimedia pembelajaran hasil pengembangan pada aspek media secara keseluruhan yaitu: 155 tanggapan sangat baik, 203 tanggapan baik, 58 tanggapan cukup. Sedangkan penjelasan tiap butir, dipaparkan secara detail sebagai berikut: (1) pada butir kejelasan petunjuk penggunaan media, responden memberikan penilaian sangat baik sebanyak 13, baik sebanyak 17, dan cukup sebanyak 2. Skor rata-rata keseluruhan penilaian pada butir kejelasan petunjuk penggunaan media sebesar 4,34 setelah dikonversikan pada skala 5 termasuk kategori sangat baik, (2) pada butir keterbacaan tulisan, responden memberikan penilaian sangat baik sebanyak 8 , baik sebanyak 23 , dan cukup sebanyak 1 . Skor rata-rata keseluruhan penilaian pada butir keterbacaan tulisan sebesar 4,22 setelah dikonversikan pada skala 5 termasuk kategori sangat baik, (3) pada butir kejelasan gambar, responden memberikan penilaian sangat baik sebanyak 15 , baik sebanyak 15, dan cukup sebanyak 2 . Skor rata-rata keseluruhan penilaian pada butir kejelasan gambar sebesar 4,41 setelah dikonversikan pada skala 5 termasuk kategori sangat baik, (4) pada butir ketepatan jenis dan ukuran tulisan, responden memberikan penilaian sangat baik sebanyak 10, baik sebanyak 19, dan cukup sebanyak 3 . Skor rata-rata keseluruhan penilaian pada butir ketepatan jenis dan ukuran tulisan sebesar 4,22 setelah dikonversikan pada skala 5 termasuk kategori sangat baik, (5) pada butir kualitas gambar, responden memberikan penilaian sangat baik sebanyak 11 , baik sebanyak 17 , dan cukup sebanyak 4 . Skor rata-rata keseluruhan penilaian pada butir kualitas gambar sebesar 4,22 setelah dikonversikan pada skala 5 termasuk kategori sangat baik, (6) pada butir warna latar belakang, responden memberikan penilaian sangat baik sebanyak 18, baik sebanyak 9, dan cukup sebanyak 5 . Skor rata-rata keseluruhan penilaian pada butir warna latar belakang sebesar 4,41 setelah dikonversikan pada skala 5 termasuk kategori baik, (7) pada butir tampil- an tiap slide, responden memberikan penilaian sangat baik sebanyak 10, baik sebanyak 15 , dan cukup sebanyak 7 . Skor rata-rata keseluruhan penilaian pada butir tampilan tiap slide sebesar 4,09 setelah dikonversikan pada skala 5 termasuk kategori baik, (8) pada butir ketepatan musik pengiring, responden memberikan penilaian sangat baik sebanyak 2, baik sebanyak 11, dan cukup sebanyak 19. Skor rata-rata keseluruhan penilaian pada butir ketepatan musik pengiring sebesar 3,47 setelah dikonversikan pada skala 5 termasuk kategori baik, (9) pada butir kebebasan memilih menu, responden memberikan penilaian sangat baik sebanyak 14 , baik sebanyak 13, dan cukup sebanyak 5. Skor rata-rata keseluruhan penilaian pada butir pemberian respon yang tepat sebesar 4,28 setelah dikonversikan pada skala 5 termasuk kategori sangat baik, (10) pada butir kemudahan memilih menu, responden memberikan penilaian sangat baik sebanyak 18, baik sebanyak 13, dan cukup sebanyak 1 . Skor rata-rata keseluruhan penilaian pada butir kebebasan memilih menu sebesar 4,53 setelah dikonversikan pada skala 5 termasuk kategori sangat baik, (11) pada butir kejelasan fungsi tombol, responden memberikan penilaian sangat baik sebanyak 15 , baik sebanyak 13, dan cukup sebanyak 4 . Skor rata-rata keseluruhan penilaian pada butir kejelasan fungsi tombol sebesar 4,34 setelah dikonversikan pada skala 5 termasuk kategori sangat baik, (12) pada butir ketepatan pemilihan animasi, responden memberikan penilaian sangat baik sebanyak 16 , baik sebanyak 13 , dan cukup sebanyak 3. Skor rata-rata keseluruhan penilaian pada butir ketepatan pemilihan animasi sebesar 4,41 setelah dikonversikan pada skala 5 termasuk kategori sangat baik, (13) pada butir kecukupan soal pada tes, responden memberikan penilaian sangat baik sebanyak 5 , baik sebanyak 25 , cukup sebanyak 2. Skor rata-rata keseluruhan penilaian pada butir kecukupan soal pada tes sebesar 4,09 setelah dikonversikan pada skala 5 termasuk kategori baik. 
Hasil analisis data uji coba kelompok besar, dapat dikatakan bahwa produk multimedia pembelajaran kimia hasil pengembangan ditinjau dari aspek pembelajaran, aspek materi maupun aspek media mendapat nilai $\mathrm{B}$ termasuk dalam kategori baik.

\section{Simpulan dan Saran}

Simpulan

Berdasarkan hasil analisis data penelitian dan pengembangan, simpulan hasil penelitian dapat disebutkan sebagai berikut: (1) multimedia pembelajaran kimia hasil pengembangan ini sudah dikembangkan menggunakan kaidah-kaidah pengembangan yang meliputi: identifikasi, desain, produksi, uji coba dan revisi, serta implementasi, (2) multimedia pembelajaran kimia hasil pengembangan ditinjau dari aspek pembelajaran, memiliki kualitas termasuk dalam kategori baik dengan skor rata-rata 4,07, (3) multimedia pembelajaran kimia hasil pengembangan ditinjau dari aspek materi, memiliki kualitas termasuk dalam kategori baik dengan skor rata-rata 4,11, (4) multimedia pembelajaran kimia hasil pengembangan ditinjau dari aspek media, memiliki kualitas termasuk dalam kategori sangat baik dengan skor rata-rata 4,23, (5) produk pengembangan media pembelajaran kimia berbantuan komputer dengan program Macromedia Flash 8 ditinjau dari aspek kelayakan materi, kelayakan media, dan hasil uji coba berkualitas baik dan layak untuk digunakan oleh peserta didik kelas $X$.

\section{Saran}

Berdasarkan simpulan hasil penelitian yang terdiri dari tanggapan ahli materi, tanggapan ahli media, tanggapan peserta didik dengan hasil baik dan apa yang diperoleh oleh peserta didik setelah menggunakan multimedia hasil pengembangan, maka produk multimedia pembelajaran hasil pengembangan ini disarankan untuk dapat dimanfaatkan peserta didik maupun guru dalam pembelajaran kimia, sehingga peserta didik mendapatkan model pembelajaran yang berbeda dari pembelajaran konvensional yang biasa dilakukan oleh guru. Kegiatan pembelajaran dengan multimedia ini dapat dilakukan secara mandiri maupun berkelompok.

Produk akhir multimedia pembelajaran ini dikemas dalam bentuk Compact Disc (CD) interaktif yang rencananya akan disebarluaskan ke semua pengguna. Untuk tahap awal direncanakan penyebarluasan melalui pertemuan Musyawarah Guru Mata Pelajaran (MGMP) Kimia di Kabupaten Sleman Propinsi Daerah Istimewa Yogyakarta. Dengan harapan melalui guru-guru tersebut produk multimedia pembelajaran kimia hasil pengembangan ini diimplementasikan di sekolah masing-masing.

Multimedia pembelajaran yang dikembangkan dalam penelitian ini, masih terbatas hanya satu SK dengan materi Tata Nama dan Persamaan Reaksi, Hukum-hukum Dasar Kimia dan Perhitungan Kimia (Stoikiometri), sehingga belum seluruh materi kelas $X$ untuk peserta didik SMA dapat dikembangkan. Untuk itu, perlu dikembangkan multimedia pembelajaran lebih lanjut yang memuat SK yang lain.Saran dapat berupa masukan bagi peneliti berikutnya, dapat pula rekomendasi implikatif dari temuan penelitian

\section{Daftar Pustaka}

Anderson, R.H. (1994). Pemilihan dan pengembangan media untuk pembelajaran. Jakarta: Raja Grafindo Persada.

Borg, W.R., Gall, M.D. \& Gall, J.P.. (2003). Educational research, an introduction (7thed). New York: Longman.

Criswell, E.L. (1989). The design of computerbased instruction. New York: MacMillan Publishing Company.

Dick, W,. \& Carey, L. (2005). The systematic design of instruction (6 $6^{\text {th }}$ ed). New York: Longman. 
Newby, T.J., Stepich, D. A., Lehman, J. D., \& Russell, J. D. (2000). Instructional technology for teaching and learning. Upper Saddle River, New Jersey: Prentice-Hall Inc.

Sugiyono. (2010). Metode penelitian pendidikan pendekatan kuantitatif, kualitatif dan RED. Bandung: Alfabeta.
Sukardjo. (2005). Evaluasi pembelajaran. Diktat mata kuliah evaluasi pembelajaran. Tidak diterbitkan PPs. UNY.

Syaodih, N. (2006). Metode penelitian pendidikan. Bandung: PT. Remaja Rosdakarya. 